\title{
The Development of Research-Based Learning Management in the Curriculum Design and Development Course for Teacher Students
}

\author{
Wittaya Worapun ${ }^{1}$ \\ ${ }^{1}$ Faculty of Education, Mahasarakham University, Thailand \\ Correspondence: Wittaya Worapun, Faculty of Education, Mahasarakham University, Thailand.
}

Received: September 8, 2021

Accepted: October 15, $2021 \quad$ Online Published: October 22, 2021

doi:10.5539/jel.v10n6p62

URL: https://doi.org/10.5539/jel.v10n6p62

\begin{abstract}
The purposes of the current study are to develop research-based learning management in the Curriculum Design and Development course for student teachers and to study the effectiveness of the research-based learning management in the Curriculum Design and Development course for student teachers. The instruments were a structured interview form, a learning management quality assessment, learning management, a learning achievement test, and a questionnaire. The data were analyzed by mean score, standard deviation, t-test, and content analysis. The results of the study indicate that there were 6 components including ground theories, objectives, instruction processes, social system, principles in responses and supportive system, and learning management in the research-based learning management. In detail, there were 5 stages in learning management including ideas and information analysis, planning and creative design, action-taking, presentation and reflection, and evaluation and improvement. The result of the study shows that there was a significant difference between the students' learning achievement before and after learning with the developed learning management. The students' attitudes toward learning management were found at a high level in every aspect.
\end{abstract}

Keywords: teaching style, research-based learning, Curriculum Design and Development

\section{Introduction}

Curriculum development is an essential skill for student teachers since they need to use it to formulate an appropriate curriculum for institutions they work to ensure their career development. Carl (2009) suggested that teachers play a great part in curriculum development as they are personnel that takes policy from the ministry and applies it in their context. Therefore, knowledge, experiences, and competencies in curriculum design and development need to be acquired during the processes of teacher training. The ability in implicating the core curriculum in writing a syllabus is important for student teachers as it allows them to write a syllabus that responses to the needs of learners.

However, formulating the curriculum development ability is not an easy task. To note that a curriculum needs to be designed considering the needs of society makes it complicate for curriculum developers. According to Handler (2010), it requires insightful consideration of contextual factors to bring about students' learning achievement. As a matter of fact, cultures, traditions, economy, and society need to be thoroughly discussed to implicate a core curriculum into an institutional curriculum. Consequently, instructors of curriculum development courses face the challenges to formulate the ability to design a contextually appropriate curriculum for their students. In this case, students need to be self-regulated learners to allow themselves to study their context in detail. Moreover, scientific and systematic information processing and data presentation are essential abilities in designing a well-written curriculum.

According to Dambudzo (2015), research-based learning (RBL) is a method in learners' development focusing on applying processes in research design as the main activity. The learning method is capable of innovating new knowledge in each specific area, and it also contributes to the creative and analytical abilities of learners. To clarify, research is a process that helps learners to manage their knowledge, form learning autonomy behaviors, and understand learning surroundings. In conducting a research study, a researcher needs to process and present data systemically. Therefore, learners in a course designed in research-based learning are instructed to process information to synthesize problems, considerably select methods to find solutions, systemically design data collection processes, and scientifically present the result of the study. There are 4 types of research-based learning including 1) the uses of research results in teaching (by teachers), 2) the uses of research results in 
learning (by learners), 3) the uses of research processes in teaching (by teachers), and 4) the uses of research processes in learning (by learners) (Choowong \& Worapun, 2021; Nuengchalerm, 2013). According to Kent (2014), the research result and research processes could be integrated into teaching to let students understand the information they are learning as well as acquire new knowledge through systematic planning and execution that could contribute to autonomy in learning and uses of high-level thinking. Khammanee (2014) stated that RBL is beneficial in boosting learners' self-esteem as it trains them to make decisions based on scientific evidence which can be reasonably discussed with teachers and peers. Therefore, it could be claimed that research-based learning (RBL) is an essential learning management method that could be applied in curriculum development classes as it could bring about essential skills contributing to curriculum development skills.

With the potential of research-based learning (RBL) as a learning management method in developing curriculum development skills for student teachers. Scholars have been investigating the effectiveness of the method, and the results of the studies reveal an interesting issue in the area (e.g., Granjeiro, 2019; Jiraro et al., 2020; Khumraksa, 2021; Noguez \& Neri, 2019). In detail, Noguez and Neri (2019) found that RBL was effective in developing occupational skills in engineering. Granjeiro (2019) is beneficial in contributing student motivation skills among student teachers. Jiraro et al. (2020) found that RBL benefited student teachers' teaching skills in various aspects while Khumraksa (2021) suggested that RBL enabled active learning skills of student teachers in higher education and brought about satisfaction in learning with the method.

It could be noted that research-based learning (RBL) has been proved to be beneficial in developing educational classes as it enables self-regulated learning skills, scientific information processing skills, and systematic data presentation skills. These skills are useful in designing a curriculum - an important skill for student teachers. Consequently, research-based learning (RBL) was employed in the current study as the principle in designing learning management to developing student teachers' curriculum development skills. The purposes of the study were 1) to develop research-based learning management in the Curriculum Design and Development course for student teachers and 2) to study the effectiveness of the research-based learning management in the Curriculum Design and Development course for student teachers.

\section{Research Methodology}

\subsection{Research Design}

The current study was designed in a research and development approach (R\&D). The scope of the population was in the General Science teaching department, the Faculty of Education, Mahasarakham University, Thailand. The scope of time was in the 2nd semester of the 2019 academic year and the 1st semester of the 2020 academic year. The dependent variable was the research-based learning management in the Curriculum Design and Development course for student teachers while the independent variables were student teachers' learning achievement in curriculum design and student teachers' attitudes toward the learning management.

\subsection{Data Collection}

The study was divided into 3 phases which can be seen below.

1) In phase 1, the problems and needs in developing research-based learning management were studied to reveal the current situation in the context. The participants were 5 experts in the area selected by purposive sampling. The participants took part in a focus group discussion to synthesize information used in the learning management developing processes.

2) In phase 2, the data gathered in phase 1 were analyzed and used in developing the research-based learning management in the Curriculum Design and Development course for student teachers. The participants were 5 experts in the area selected by purposive sampling who took part in the learning management evaluation. The learning management was later tried out in a preliminary study involving 21 third-year students in the General Sciences Teaching department, the faculty of Education, Mahasarakham University. The instruments were a learning management evaluation form, a tentative model designed using the data in phase 1, a learning achievement test with a reliability of 0.82 , and a questionnaire for investigating the participants' attitude toward the developed curriculum with a high level of appropriateness ( $\overline{\mathrm{x}}=4.03$, S.D. $=0.78)$.

3) In phase 3, the developed learning management was applied to develop student teachers' learning achievement in curriculum development and ability in school curriculum development. The students' attitudes toward the developed curriculum were also investigated. The participants were 30 student teachers in third-year students in the General Sciences Teaching department, the faculty of Education, Mahasarakham University selected by the purposive sampling method. The participants enrolled in the Curriculum Design and Development course in the 1 st semester of the 2020 academic year. The data collection lasted 16 weeks divided 
into 3 hours a week. The instruments were the research-based learning management in the Curriculum Design and Development course for student teachers, a learning achievement test, and a questionnaire for investigating the participants' attitude toward the developed curriculum.

\subsection{Data Analysis}

There were both quantitative and qualitative data gathered in the study. The quantitative data were analyzed by mean score, standard deviation, and a paired-sample t-test. The qualitative data were analyzed using a qualitative analysis.

\section{Results}

After the processes of data collection, the results of the study are discussed following the purposes of the study which can be seen below.

\subsection{To Develop Research-Based Learning Management in the Curriculum Design and Development Course for Student Teachers}

The results of the study indicate that there were 6 components including ground theories, objectives, instruction processes, social system, principles in responses and supportive system, and learning management in the research-based learning management. The focus group discussion of 5 experts in designing learning management with research-based learning principles indicated 5 stages of the teaching plan. Stage 1-ideas and information analysis, emphasizes teaching students to design each learning purpose in a curriculum. Stage 2 -planning and creative design, instructs students processes of developing lesson plans, choosing teaching strategies, and selecting assessment tools. Stage 3-action taking, is to analyze purposes of classes, design learning management, develop learning skills, synthesize the knowledge in classes, and evaluate classes. Stage 4 - presentation and reflection is to formulate systematic presentation and reflection skills for students. Stage 5-evaluation and improvement, is to let students practice evaluation of classes before and after instruction.

The evaluation of the learning management by experts indicates high levels of appropriateness in components and patterns of learning, principles and theories used in the design, purposes of the learning management, procedures of learning management, the social system of learning management, and the principle of learning management evaluation. It could be interpreted that the developed learning management is an appropriate method used to develop student teachers' curriculum development skills. The detail of the learning management evaluation is illustrated in Table 1.

Table 1 The evaluation of the research-based learning management in the Curriculum Design and Development course for student teachers

\begin{tabular}{lllll}
\hline No. & Issues & $\overline{\mathbf{x}}$ & S.D. & Interpretation \\
\hline 1 & Components and patterns of learning & 3.85 & 0.81 & High \\
2 & Principles and theories used in the design & 3.8 & 0.97 & High \\
3 & Purposes of the learning management & 3.96 & 0.94 & High \\
4 & Procedures of learning management & 4.30 & 0.66 & High \\
5 & The social system of learning management & 4.20 & 0.60 & High \\
6 & The principle of learning management evaluation & 4.09 & 0.71 & High \\
& Average & 4.03 & 0.78 & High \\
\hline
\end{tabular}

3.2 To Study the Effectiveness of the Research-Based Learning Management in the Curriculum Design and Development Course for Student teachers

The learning management was implemented with 30 General Science teaching majored students to investigate its effectiveness in developing the participants' learning achievement. Moreover, the participants' attitudes toward learning management were also studied to provide a broader picture of the management effects. The results of the study can be seen below.

Table 2. The effects of the research-based learning management in the Curriculum Design and Development course for student teachers on students' learning achievement

\begin{tabular}{llllllll} 
& & $\mathbf{N}$ & Full mark & $\bar{x}$ & S.D. & t & p \\
\cline { 2 - 7 } & Pre-test & 30 & 30 & 12.37 & 1.40 & 28.35 & $.00 * *$ \\
\\
Post-test & 30 & 30 & 24.37 & 1.71 & & \\
\hline
\end{tabular}

Note. $* * \mathrm{p}<01$ 
The result of the study indicates that the average score of students' learning achievement in pretest was found at 12.37 (S.D. $=1.40)$ while the average score in the posttest was $24.37(\mathrm{~S} . \mathrm{D} .=1.71)$. A pair sample t-test indicates a significant difference between the students' learning achievement scores at a statistical level of .01 ( $\mathrm{p}=0.00)$. It could be interpreted that the research-based learning management in the Curriculum Design and Development course for student teachers positively affected students' learning achievement in the Curriculum Design and Development course.

The result of the study also indicates a positive attitude toward the research-based learning management in the Curriculum Design and Development course for student teachers. The average score of the questionnaire was at a high level $(\bar{X}=4.15$, S.D. $=0.79)$. Moreover, the top three most rated items are "RBL encouraged me to pay respect to curriculum development colleagues even in a moment of disagreement" ( $\bar{X}=4.67$, S.D. $=0.48)$, "RBL encouraged me to connect schemata to new knowledge" $(\bar{X}=4.50$, S.D. $=0.78)$, and "RBL encouraged me to finish assignments with punctuation" $(\bar{X}=4.50$, S.D. $=0.51)$, respectively. The detail of the students' attitudes toward learning management can be seen below.

Table 3. The participants' attitudes toward the research-based learning management in the Curriculum Design and Development course for student teachers

\begin{tabular}{|c|c|c|c|c|}
\hline No. & Items & $\bar{X}$ & S.D. & Interpretation \\
\hline 1 & RBL consisted of motivating questions for self-learning. & 4.00 & 0.83 & Agree \\
\hline 2 & RBL allowed me to practice designing a curriculum using research processes. & 4.00 & 0.83 & Agree \\
\hline 3 & RBL encouraged me to find more information to use in curriculum development & 4.17 & 0.70 & Agree \\
\hline 4 & RBL encouraged me to use various sources in curriculum design. & 4.00 & 0.83 & Agree \\
\hline 5 & $\begin{array}{l}\text { RBL encouraged me to frequently take notes of important information in curriculum } \\
\text { development. }\end{array}$ & 4.00 & 1.17 & Agree \\
\hline 6 & $\begin{array}{l}\text { RBL supported a physical learning environment that is appropriate for activities related to } \\
\text { curriculum development. }\end{array}$ & 4.00 & 0.83 & Agree \\
\hline 7 & $\begin{array}{l}\text { RBL consisted of activities that help learners to formulate the scope of curriculum } \\
\text { development. }\end{array}$ & 4.17 & 0.70 & Agree \\
\hline 8 & RBL allowed me to review research and curriculum developing processes. & 4.00 & 0.83 & Agree \\
\hline 9 & RBL allowed me to search for further information. & 3.83 & 1.09 & Agree \\
\hline 10 & RBL encouraged me to connect schemata and new knowledge & 4.50 & 0.78 & Agree \\
\hline 11 & RBL encouraged me to be a self-regulated learner. & 3.83 & 1.09 & Agree \\
\hline 12 & RBL allowed flexible time management. & 3.83 & 1.09 & Agree \\
\hline 13 & RBL encouraged me to take responsibility for designing an institutional curriculum. & 4.17 & 0.70 & Agree \\
\hline 14 & RBL encouraged me to take part in every process of curriculum development. & 4.33 & 0.76 & Agree \\
\hline 15 & RBL boosted my self-esteem in designing a curriculum. & 4.33 & 0.76 & Agree \\
\hline 16 & RBL encouraged learning autonomy. & 4.17 & 0.70 & Agree \\
\hline 17 & RBL encouraged me to finish assignments with punctuation. & 4.50 & 0.51 & Agree \\
\hline 18 & $\begin{array}{l}\text { RBL encouraged me to show respect to curriculum development colleagues even in a } \\
\text { moment of disagreement. }\end{array}$ & 4.67 & 0.48 & Strongly agree \\
\hline 19 & RBL provided more enjoyable group works. & 4.33 & 0.48 & Agree \\
\hline 20 & RBL encouraged me to have a positive attitude toward work even in difficult moments. & 4.17 & Agree & Agree \\
\hline Average & & 4.15 & 0.79 & Agree \\
\hline
\end{tabular}

\section{Discussions}

The results of the study indicated that the research-based learning management in the Curriculum Design and Development course for student teachers was developed and evaluated to be appropriate for developing student teachers' curriculum development learning achievement. The developed learning management is also found to be beneficial in developing the participants' learning achievement of curriculum design. Moreover, the participants showed a positive attitude toward learning with the learning management designed by the principle of research-based learning. The results of the study could be discussed in various aspects below.

First, the effectiveness of the learning management in developing participants' learning achievement in the Curriculum Design and Development course might rely on the design of learning management. In detail, 5 stages are involved in the development of research-based learning.

The processes of idea and information analysis instructed in the early stage of the learning management were beneficial for the participants to systemically gather and synthesize information to set the purposes of the designed curriculums. 
At the planning and creative design, the participants could use the information in the first stage to design the detail of the curriculum. Nissim (2020) stated that RBL provides opportunities for learners to discuss the possibility of plans with colleagues. This helps them to issue the detail of the curriculum in terms of teaching media, teaching method, and assessment within the limited time and contextual regulations (Neungchalerm, 2020).

At the third stage, the designed curriculums were taken into action. The participants were allowed to analyze, criticize, and evaluate their curriculums and gather beneficial information to improve them.

At the presentation and reflection stage, the participants were allowed to practice giving a scientific and creative presentation of their findings. Worrapun (2019) suggested that presentation also allows learners to reflect on the problems in their design. Autonomy in learning needs to be acquired as it brings about the considerate synthesis of data to identify flaws of design and solutions to the problems.

Lastly, the participants were allowed to practice evaluating instruction both in classes and after classes. Prachagool and Neungchalerm (2011) suggested that evaluation of teaching would reflect the quality of curriculum since developers could compare teaching methods to the purposes of each lesson. Problems found in the evaluation could also be applied with other principles such as the psychology of learning and teaching strategies in curriculum improvement processes.

These principles of learning management design could help the participants to comprehend the processes of curriculum development and results in the significant difference between their learning achievement scores before and after learning with the developed learning management. The result of the study is consistent with Art-in and Netthanomsak (2010), Granjeiro (2019), Jiraro et al. (2020), Khumraksa (2021), Noguez and Neri (2019) who also found the benefits of RBL as a principle of designing learning management that is capable in developing learners' skills.

The result of the study also reveals participants' positive attitudes toward the developed learning management. It could be noted that research-based learning encourages learners to take part in all processes of learning. In the current study, learners needed to research information to make a plan in curriculum design. They also had to take the developed curriculums into action, present, and evaluate them. These bring about considerate participation in the design and a positive attitude toward learning management. The result of the study is related to Khumraksa (2021) who suggested that RBL could also result in a positive attitude toward learning as it is a principle that connects learners to the tasks and builds up both target skills and desirable learning behaviors.

\section{Conclusion}

The results of the study could be concluded that the learning management in the Curriculum Design and Development course for student teachers was developed using the principles of research-based learning (RBL) having 5 stages of learning. The developed learning management was found to be appropriate in developing student teachers' curriculum developing skills. It could also be concluded that the developed learning curriculum was effective in developing learners' curriculum developing skills since the learning management resulted in the improvement of the participants' learning achievement and participants' positive attitudes in learning. Additionally, RBL could be implemented in classes as it contributes to cooperative learning, supportive learning, and learning autonomy. Further studies could integrate RBL into other principles such as problem-based learning to develop learners' skills. Moreover, RBL could also be used as a principle in learning management design to develop other skills of student teachers such as distance learning management and online learning management which are important in the current situation.

\section{Acknowledgment}

The current study was funded by the Faculty of Education, Mahasarakham University.

\section{References}

Art-in, S., \& Netthanomsak, T. (2010). Project-based learning in curriculum development course for five-year bachelor's degree students. KKU Research Journal, 1(1), 1-16.

Carl, A. (2009). Teacher empowerment through curriculum development: Theory into practice. Cape Town, South Africa: Juta and Company.

Choowong, K., \& Worapun, W. (2021). The development of scientific reasoning ability on concept of light and image of grade 9 students by using inquiry-based learning $5 \mathrm{e}$ with prediction observation and explanation strategy. Journal of Education and Learning, 10(5), 152-159. https://doi.org/10.5539/jel.v10n5p152

Dambudzo, I. (2015). Curriculum issues: Teaching and learning for Sustainable. Journal of Education and 
Learning, 4(1), 11-24. https://doi.org/10.5539/jel.v4n1p11

Granjeiro, E. M. (2019). Research-based teaching-learning method: A strategy to motivate and engage students in human physiology classes. Advances in Physiology Education, 43(4), 553-556. https://doi.org/10.1152/advan.00034.2019

Handler, B. (2010). Teacher as curriculum leader: A consideration of the appropriateness of that role assignment to classroom-based practitioners. International Journal of Teacher Leadership, 3(3), 32-42.

Jiraro, P., Phothisuk, A., Suwanaruji, A., Klosawasdi, P., \& Jiraro, S. (2020). Research and development of a research-based learning model (RBL) in teaching students of the faculty of education ST. Theresa International College. St. Theresa Journal of Humanities and Social Sciences, 6(2), 194-209.

Kent, L. (2014). Students' thinking and the depth of the mathematics curriculum. Journal of Education and Learning, 3(4), 90-95. https://doi.org/10.5539/jel.v3n4p90

Khammanee, T. (2014). Teaching sciences: Effective learning management. Bangkok, Thailand: Chulalongkorn University Press.

Khumraksa, B. (2021). The Use of Research-Based Learning to Promote an Active Learning in Science Learning. CMU Journal of Education, 5(1), 58-74.

Nissim, Y. (2020). Draw me a shepherd: Student-teachers' perceptions and metaphors on the image of the "leader-teacher". Higher Education Studies, 10(2), 24-37.

Noguez, J., \& Neri, L. (2019). Research-based learning: A case study for engineering students. International Journal on Interactive Design and Manufacturing, 13, 1283-1295. https://doi.org/10.1007/s12008-019-00570-x

Nuangchalerm, P. (2013). Engaging nature of science to pre-service teachers through the inquiry-based classroom. Journal of Applied Science and Agriculture, 8(3), 200-203.

Nuengchalerm, P. (2020). Curriculum Design. Mahasarakham, Thailand: Klungnawitaya Press.

Prachagool, V., \& Nuengchalerm, P. (2011). Patterns in learning and teaching. Mahasarakham Thailand, Mahasarakham University Press.

Worapun, W. (2019). The design and development of sciences curriculum. Mahasarakham Thailand, Mahasarakham University Press.

\section{Copyrights}

Copyright for this article is retained by the author, with first publication rights granted to the journal.

This is an open-access article distributed under the terms and conditions of the Creative Commons Attribution license (http://creativecommons.org/licenses/by/4.0/). 